\title{
Cyber Crime Hate Speech Criminological Review in 2018-2019 (Case Study in Salatiga City)
}

\author{
Putra Sang Fajar El Harry ${ }^{1}$, Riswadi ${ }^{2}$ \\ University of Borobudur ${ }^{1,2}$ \\ \{drputrasangfajar@gmail.com¹ ,riswadi@borobudur.ac.id² ${ }^{2}$,
}

\begin{abstract}
Efforts to realize legal ideals to prosper society through criminal law policy are not the only way to have the most strategic role. The approach used in this study is empirical, i.e., legal research on the application or implementation of normative legal provisions in action on every particular legal event that occurs in society. From this study, the Police can handle and handle the crime of cybercrime hate speech in the area of Salatiga City. The National Police have formed a cyber team in cooperation with the national cyber agency.
\end{abstract}

Keywords: Speech Kebencian; Cyber Crime; Tindak Pidana

\section{Introduction}

Efforts to realize legal ideals to prosper society through criminal law policy are not the only way to have the most strategic role. It is said to be so because criminal law is only one of the means of community control. Information and communication technology has changed people's behavior and human civilization globally. Besides, the development of information technology has caused the world to become limitless and led to social change that is significantly rapid.

Today's information technology is significant in contributing to the improvement of human welfare, progress, and civilization and being a practical arena of unlawful acts. There has been born a new legal regime known as Cyber Law, which is taken from the word Cyber Law is a legal term related to the utilization of information technology. Other terms used are LawOf InformationTechnology, Virtual World Law. These terms were born given the internet activities and the utilization of virtual-lined information technology. The term cyber law used in this paper is based on the idea that cyber if identified with "Cyberspace," will be enough to face problems if it has to prove an issue that is assumed to be "virtual," something invisible and pseudo.

There are three approaches to maintaining security in cyberspace, the first being the technology approach, the second the socio-cultural-ethical approach, and the third the legal approach. To overcome the technology approach's security disruption, it will be straightforward to infiltrate, intercept, or access illegally and without rights (Supriyanto, 2018). Information becomes a significant thing for people who will look for a piece of certain information that suits their needs in the information age. No less critical the accuracy of the data obtained becomes a reason to use information and communication technology (ICT). In 
this case, ICT becomes a medium that answers human needs to fulfill information and communication.

Information and communication technology (ICT) has brought people to a new civilization with social structures and values arranged in such away. In its development, computers have been found as a product born of information and communication technology. Computer, according to Law No. 11 of 2008 on Information and Electronic Transactions in Article 1 point 14, namely: a valuable tool for processing electronic, magnetic, optical, or system data that performs logical, arithmetic, and storage functions.

With the Internet, people can do activities like life in the real world. People can do various things and activities in the internet world, ranging from just chatting, online business transactions, shopping in virtual stores, etc. The Internet seems to have formed a new reality that creates a new world, thus inadvertently dividing this life into two, namely life in the real world and life in the virtual world.

Most internet users(netter) believe it is a new natural presence that has no legal provisions, regardless of the system's existence and irrespective of the legal system in force, because of the absence of an absolute single mastery in large computers' network (massive network). Thus, the virtual world built through the internet network can build great excitatory and emotional power. On the one hand, internet users can fulfill their curiosity about cyberspace. On the other hand, the Internet also presents various things that can cause positive and negative effects for its users. The Internet has built a virtual world without borders and a world that anyone can enter and utilize.

Hate Speech (in English) or hate speech became a hot topic in various media in Indonesia in early November 2015. The emergence of hate speech polemic, starting from the publication of Circular Letter (SE) of the Chief of Police of the Republic of Indonesia (Kapolri) Number SE/06/X/2015. The letter was signed on October 8, 2015. The letter is addressed to all units of the Regional Police (Polda) throughout Indonesia. However, the emergence of SE raises a variety of positive and negative assumptions. Political figures and the public, in general, respond to that, but people in the cyber world, especially those actively involved in Social Media, also respond differently.

Actions or crimes that need to get serious attention at this time hate Speech itself is Acts of communication conducted by an individual or group in the form of provocation, incitement, or insult to other individuals or groups in terms of various aspects such as race, color, gender, defects, sexual orientation citizenship, religion, and others. So the cause of a person committing hate speech crimes in social media because of the inside or outside of the person who is likely to progress from information that can be accessed quickly and effectively through various media. Thus theology can also be said to also beacriminogen a factor that is a factor y ang cause the onset of people's desire to do evil or make it easier for people to commit crimes, such as crimes, in this case, speech hatred through social media.

Ethics in the online world today needs to be established to prevent even greater crimes and violations, given the online world that has become an essential part of the communication and information infrastructure, moreover more and more people are abusing cyberspace to disseminate their displeasure with something that concerns ethnicity, religion, and race. This is called hate speech. Based on the criminological aspects that exist today, the authors consider that many factors that cause Indonesians to prefer to devote all kinds of thoughts, opinions, and creations in social media than directly, but they do not realize what they are doing is true or not, violate the norms or not, troubling or not and violating the human rights of others or not so that analysis of the factors that cause the crime. 
It was so based on the case that occurs the cause of a person committing hate speech crimes in social media. From within or outside, the person is likely to progress from information that can be accessed quickly and effectively through various media. Thus theology can also be a criminogenic factor that causes the onset of people's desire to do evil, in this case, Hate speech through social media.

\section{Methodology}

The research approach is a way of thinking that researchers adopt about how research design is made and how it will be conducted. The method used in this research is empirical, i.e., legal research on applying or implementing normative legal provisions in action on every particular legal event in society (empirical facts).

This type of research is descriptive research, a research method that utilizes qualitative data and is described descriptively. Qualitative descriptive research types are often used to analyze events, phenomena, or social circumstances. The source of the research data comes from library data and field data. In comparison, the data type consists of primary data and secondary data-methods of collecting data with interviews, documentation, and document libraries.

\section{Result and Discussion}

\subsection{Criminological Review on Cyber Crime Hate Speech in the Legal Area of the Salatiga Police}

Salatiga Resort Police is an Organizational Unit as part of the Ministry / Government Institutions that have the main task in maintaining security and public order by providing protection, protection, services, and law enforcement. Until now, the condition of the Salatiga Police Area is still quite conducive because it can not be separated from the hard work of all members of the Salatiga Police and for support and cooperation with the Government of Salatiga City, DPRD, TNI, Educational Institutions, Government agencies and private as well as participation from various community communities salatiga city.

Salatiga Police has until now built the ability of public services per standard operational procedures, to realize a public service that is cheap, fast transparent, and accountable and can increase public confidence in the performance of the Police better; thus the negative impression of the past will turn into a police force that is loved and trustworthy by the community, to realize the city of Salatiga safe, peaceful and conducive.

In dealing with all forms of potential security disruptions and problems faced by the Salatiga Police, it must establish and implement the Vision and Mission and orient on objectives, objectives, strategies, and policies as an institution and institution that is independent, global-minded, nationally oriented and not local full of coordination and energy in providing, implementing prevention and law enforcement to the community.

With the Vision and Mission and oriented to the Objectives, Objectives, Strategies, and policies directed to synergize, it will be able to awaken and encourage all members of salatiga police to be more intelligent, cultured balanced with good morals and able to increase creativity and full of innovation in the face of increasingly challenging and complex tasks in providing services and law enforcement. 
Since October 2015, the Republic of Indonesia's State Police has had guidelines to crack down on hate speech perpetrators, namely Circular Letter (SE) Police Chief No. 6 the Year 2015 on Handling hate speech (hate speech). Police have also been carrying out law enforcement of the perpetrators. Hate speech can break up the unity and unity of the nation and create social conflict. The policy has been encouraged by civil society groups to address the growing rise of hate speech that impacts social conflict in Indonesia. Various acts of hate speech in Indonesia have occurred almost without any countermeasures from the state.

Hate-taking involves offense-givingandoffence-taking. Hate speech is often directed at vulnerable groups, such as religious minorities, ethnicities, sexual orientations, etc. When a vulnerable group 'acts', hate preachers regard it as an insult or blasphemy and move its group to attack susceptible groups. This is incitement. Unlike hate speech that can be restricted if it involves violence, incitement is very subjective. Here, hate preachers instead use the free space of democracy to promote its intolerant values.

Based on the results of the interview, obtained the result "Not all incitement to hatred must be resolved through criminalization or responded with the same action, depending on the context. Although all hate incitement is basically bad, one incitement to hatred can be worse than another, for example blatantly involving many people, so the threat of danger is greater. Any action against hateful incitement must consider these things. The most appropriate action against hateful incitement is to not severely restrict freedom of expression, but to counteract the dangers it may pose. "

Usually heading into a political year, the hoaks that circulate contain a lot of attacks on certain identities or groups. First, the content and tone of incitement: some use subtle language and false information about a group, but some use more extreme language and blatantly call on others to commit violence. Second, the intent of the perpetrator of incitement, whether to injure or incite; incitement is sometimes intentional but sometimes accidental. The expression below is equally bad and intolerant, but it may be different intentions, so it needs to be responded to differently. Third, a potential target or target is a vulnerable group: some people or groups are more vulnerable than others, whether it's because of the treatment of society, the media, or the state of the group itself that can't defend itself or defend itself. Fourth, context: pay attention to the culture and history around incitement, including the media, targeted audiences, prejudices that exist in society, as well as the 'authority' of incitement actors, and so on. Fifth, the potential impact, this is the most important consideration in assessing the incitement of hatred and determining the actions against it.

We need to remember that incitement to hatred is multilevel: one is worse than the other. So is the maker and spreader: hatred is also more/less dangerous than others. In response to the makers of hate incitement, the action against them depends on the degree of seriousness of the incitement of hatred and its effects. If the level is harmless, contraration can be done by reminding it directly. But, if the level is dangerous and has a wide impact, we can report the perpetrator to the authorities. Reporting doesn't always have to be to law enforcement officials. We can report their actions to institutions that focus on hoaxes and hate speech, such as social media platform providers to have content removed or accounts blocked. We can also report hate speech to the institution where they work or school. Spreading hateful content also plays a role in violence, though not directly. They may not realize that the content they share is harmful, can hurt others, or contain fake news. Therefore, it is important to do public education that what they do can be dangerous because: (1) they justify the spread of hateful incitement; and (2) escalate or mobilize hate speech into acts of violence.

Victims Of Those who are the target of hate incitement need to be strengthened by various strategies to protect themselves in the face of hateful expressions. Their skills and knowledge 
to see the real problems need to be improved. They feel they can't do anything when their role is not to share hoaxes and fight hateful incitement is needed. Training and dialogue are needed to turn passive attitudes into active in the fight against incitement to hatred. Increased awareness of active participation is the most likely thing to do to this target.

\subsection{How to Overcome the Crime of Hate Speech}

The stages of police officers tackling hate speech can be seen in systematics as follows:

a. Preventive Stages by Binmas / Polmas

1. Do early warning and early detection;

2. Socialization on the impact of public hate speech

3. Building cooperation with religious leaders, community leaders, youth leaders and academics to optimize repressive actions on hate speech;

4. If you discover the potential for hate speech then:

a. Monitoring or early detection of the onset of the seeds of infighting

b. Approach to hate speech offenders

c. Bringing the perpetrators together with the victim

d. Seeking a peace solution while reminding the negative impact of hate speech.

b. Repressive stages through criminal proceedings

c. In the event of a social conflict refer to:

1. Social Conflict Management Act.

2. Perkap No. 8 Year 2013 On Handling Social Conflict Overall provisions on the stages of tackling hate speech is quite good.

However, there is confusion at the stage of "building cooperation with religious leaders, community leaders, youth leaders and academics to optimize repressive actions on hate speech". The purpose of hate speech as referred to above, is to incite and incite hatred against individuals and/or community groups in various communities that are distinguished from the aspects of: tribes; religion; religious traditions; beliefs; race; between groups; skin color; ethnicity; gender; people with disabilities ; and sexual orientation (letter g SE Kapolri). Such hate speech can be done through various media, among others in the oration of campaign activities; banners or banners; social media networks; public opinion (demonstration); religious lectures; print and electronic media; and pamphlet (letter h SE Kapolri).

Such actions if left unceasingly can eventually lead to collective hatred, exclusion, discrimination, violence, and even at the most egregious levels, ethnic or genocide against groups targeted by hate speech. In addition, acts of hate speech if not handled effectively, efficiently, and in accordance with the provisions of the legislation, will potentially cause widespread social conflict and potentially lead to acts of discrimination, violence, and / or loss of life (letter i SE Kapolri), therefore the Police is required to be able to deal with all matters related to hate speech actions carried out through prefensive and repressive efforts.

Freedom of speech is often misinterpreted by society, especially as the modern technological era develops. Many people liken today that the fingers are sharper than the tongue, the formulation is intended because nowadays people prefer to express their thoughts through social media, and the way used is to type on the keyboard or keypad instead of by expressing them in the forum. This problem is what gives rise to excessive courage in expressing opinions, because in fact there is no interlocutor in front of him. Different when in a discussion forum where there are discussion partners there then every word that is thrown will be really considered, so as not to hurt or even appear substance that is hate speech. 
Hate speech itself is an act of communication conducted by an individual or group in the form of provocation, incitement, or insult to another individual or group in terms of various aspects such as race, color, gender, disability, sexual orientation of citizenship, religion and others." Hate speech is found in many online media, be it on social media such as facebook, twitter, Instagram, whatsapp, and even websites. Websites that use or apply hatespeech (hate speech)are called(hate site).

Most of these sites use internet forums and news to emphasize a particular point of view. During this time, hatespeech has had an impact on human rights violations light to severe, always initially only words, both on social media, and through leaflets, but the effect is able to move the masses to trigger conflict and bloodshed. This condition, encourages to immediately bring up the actions of the authorities in dealing with hate speech in society that is felt so excessive, even to the point that it can no longer be controlled. The actions of the apparatus are not only repressive, but must also have preventive or preventive power and countermeasures in it. So that the resistance to hate speech ends to its roots.

Crime Prevention itself is an effort made to improve the social, economic situation of the community, increase legal awareness and community discipline and prevent the occurrence of repetition of criminal acts (residivis). In fact, tackling crime is an integral part of community protection efforts(social defence)and efforts to achieve community welfare (socialwelfare). Therefore, it can be said, that the ultimate goal or the main goal of tackling crime is "the protection of the community to achieve the welfare of the community. So as a form of countermeasures, the Police Chief of the Republic of Indonesia issued a Decree related to the handling ofhate speech. In the Circular letter of the Police Chief numbered SE/06/X/2015 concerning hatespeech (hate Speech)it is explained the understanding of speech hatred (hate Speech)can be a criminal act set in the Criminal Code and other criminal provisions outside theCriminal Code, which are in the form of:
a. Insult
b. Defamation
c. Blasphemy
d. Unpleasant deeds
e. Provoke
f. Incite
g. Spreading false news

This Circular Letter of the Police Chief is one of the guidelines or guidelines given by the Police Chief to its members. Through this circular hate speech it is important for members of the National Police to have an understanding and knowledge of forms of hate speech so that they can take precautions as early as possible before the onset of criminal acts as a result of such hate speech. Acts of hate speech if not handled effectively, efficiently, and in accordance with the provisions of the legislation have the potential to cause widespread social conflict and lead to acts of discrimination, violence, and/or loss of life. Based on the results of the interview from Kanit Reskrim Police Salatiga, it is stated that from the review of the criminology of the salatiga community along with the development of the times. Salatiga community average - average already have Gadgets and internet network already masu. That is not accompanied by knowledge (i.e. lack of understanding and socialization of the ITE Law. No.19 Year 2016 on Amendments to Law No. 11 of 2008 on ITE, related to internet mode cyber hate speech crime mode increased sharply. Otherwisethe mode of fraud over the Internet also increased sharply. 


\subsection{Obstacles Faced by the Police in Handling Crime Cyber Crime Hate Speech in the Legal Area of the Salatiga Police}

However, there are still some obstacles that come from internal and external encountered in the handling of hate speech crimes, while based on the results of interviews conducted in the results of these constraints are as follows:

\section{a) Tracking the Whereabouts of Perpetrators Who are in Areas Far Out of Reach}

In the process of law enforcement, facilities and infrastructure are absolutely necessary to facilitate and create legal certainty. Adequate facilities and infrastructure are intended to assist law enforcement in uncovering crimes, especially if a crime requires technological sophistication to uncover the perpetrator's crimes clearly. Salatiga Police Department in tracking the whereabouts of perpetrators who spread hate speech is supported by a technology tool called a signal tracking car, this car is equipped with sophisticated equipment that can track a person's cell phone number and can know the whereabouts of the person. So that if the Police have found the position of the perpetrator then the Police can immediately arrest him and bring him to be questioned. So if the perpetrator is in an affordable area then the Police within $1 \times 24$ hours the position can be known. However, if the position of the perpetrator is known to be in an area far from the city center or district so as to get a signal of the presence of the perpetrator will be a little difficult. Perpetrators who are in an area that is out of reach will certainly take a long time in tracking. Waktu needed to find the perpetrator of hate speech crime varies, if he is in an affordable area can be done in $1 \times 24$ hours, if the perpetrator is in an area far from the reach of The Salatiga Police Can take 2-3 days or more.

\section{b) The Perpetrator used a Fake Account}

Perpetrators who write hate speech on Facebook, Twitter, Instagram, and other social media sites in addition to using their original accounts are also found to be using fake accounts. Fake accounts here mean they use a name that doesn't belong to them, usually a pseudonym that doesn't have an element of their real name. The perpetrators who use this fake account are judged not to want to be known their identity so that they easily and freely to write or spread a hate speech. However, if the owner of the fake account has the same Internet Protocol (IP) Address as his/her real account, of course it can be tracked by filtering the names that have the same IP Address. The problem is if there is an account that has an IP Address that is not clear or has no similarity to any account and does not contain a clear identity of the owner. Such accounts are widely found after cyber patrol teams conduct patrols in cyberspace.

\section{c) Lack of Community Participation}

Low public legal awareness can be an obstacle to the law enforcement process. This can be seen from the reluctance of the public to submit a report or be a witness to the occurrence of a law enforcement process. It is recognized that the above does not merely describe the low legal awareness of the community, because there are still other factors, such as the lack of guarantees of protection of witnesses. The obstacle of the Police in dealing with hate speech is in general public awareness of hate speech crimes that are still very low. Most like-minded people are still afraid, reluctant or lazy to deal with the law. In addition, there are still people who do not understand about the meaning of hate speech itself. This makes it difficult for the 
Police to investigate hate speech crimes because the Police cannot work alone to find out the perpetrators who spread hate speech. Perpetrators of hate speech crimes often use social media tools in doing their deeds. It should be easy for the public to know the accounts of the spreaders of hate speech, but the public often does not care about it. It can be seen that there are still many accounts that write hate speech found by the cyber patrol team. In addition to the lack of public concern, with less knowledge they are often lured by such hate speech so that they can be provoked by it. The Police want the public to also help provide information about someone who is spreading hate speech or content that is considered to provoke divisions between people. The social media accounts that spread hate speech also use real accounts whose identities.

\section{Conclusion}

Factors that cause perpetrators to commit hate speech in social media, namely, factors from within the individual (internal) including the psychological and psychological state of the individual and factors from outside the individual, namely environmental factors, factors lack of social control, factors of public interest, factors of ignorance of the community, as well as factors of facilities, facilities and technological advances. However, the most common factors that cause perpetrators to commit crimes are internal factors, namely psychological or psychological actors, namely high emotional power, in addition to the factors of facilities, facilities and technological advances are also very influential because of the availability of facilities and facilities that are easy to obtain and technological advances that are increasingly sophisticated so as to make it easier for every social media user to access all information without limits. Efforts to counter the occurrence of hate speech in social media consists of efforts penal and non penal. Where the penal effort consists of sanctioning the perpetrator by giving a prison sentence in accordance with what has been stipulated in the ITE Law to provide a deterrent effect. While non-penal efforts are to provide counseling or socialization to the public about the impact information of electronic media if not used wisely, ethics of using social media by providing legal knowledge about the ITE Law.

Constraints derived from external and internal Police encountered in handling the crime of hate speech, as for these constraints are as follows:

a. Tracking the whereabouts of the perpetrators who are in an area far out ofreach. In the process of law enforcement, facilities and infrastructure are absolutely necessary to facilitate and create legal certainty. Adequate facilities and infrastructure are intended to assist law enforcement in uncovering crimes, especially if a crime requires technological sophistication to uncover the perpetrator's crimes clearly.

b. The perpetrator used a fakeaccount. Perpetrators who write hate speech on Facebook, Twitter, Instagram, and other social media sites in addition to using their original accounts are also found to be using fake accounts.

c. Lack of communityparticipation. Low public legal awareness can be an obstacle to the law enforcement process. This can be seen from the still a reluctance of the public to submit a report or be a witness to the occurrence of a law enforcementprocess. 


\section{References}

[1] Anwar, N. S. (2019). Analisis Transaksi Digital Cryptocurrency Sebagai Investasi Global Dalam Perspektif Hukum Islam (Studi Kasus Dinar Dirham di Makassar).

[2] Gordon, J. M. (1998). Business Law: An Introduction. Business Law: An Introductionby TheBusinessProfessor.Com, 501(c), 428-431.

[3] Santiago, F. (2016). Bunga Rampai Catatan Hukum. Perpustakaan Nasional RI. Katalog Dalam Terbitan.

[4] Supriyanto, Eko Eddya. 2020. Eksistensi Nilai-Nilai Pancasila Dalam Kebijakan Ekonomi Indonesia. 1st ed. Malang: Literasi Nusantara.

[5] Supriyanto, E. E. (2021). Strategi Penerapan Kebijakan Sovereign Wealth Funds (SWFs) di Indonesia: Studi Literatur dan Studi Komparatif Oman. Jurnal Inovasi Ilmu Sosial Dan Politik (JISoP), 3(1), 10-21. https://doi.org/10.33474/jisop.v3i1.6959

[6] Supriyanto, E. E. (2018). Perang Strategi Pemenangan Pemilu Via Sosial Media (Sebuah Analisis Literatur Dan Sosial Media). In L. K. Alfirdaus \& N. Hasfi (Eds.), Proceeding Seminar Nasional dan Diskusi Ilmiah Media, Pemilu dan Komunikasi Politik Menyambut Tahun Politik Indonesia 2018-2019 (pp. 122-135). Magister Ilmu Politik FISIP Universitas Diponegoro.

[7] Nababan, K. N. N. (2019). Tinjauan Legalitas Transaksi Bitcoin di Indonesia. JuristDiction, 2(5), 1745-1764. 